\title{
The Mediating Role of Customer Satisfaction in the relationship between Service Quality and Customer Loyalty
}

\author{
Kamisah Ismail ${ }^{\star}$, Jamie Wan Chiou Tin, and Jacinta Phooi M'ng Chan \\ Faculty of Business and Economics, University of Malaya, Malaysia
}

\begin{abstract}
The purpose of this paper is to examine the relationships between service quality, customer satisfaction and customer loyalty in the context of the life insurance business. The Theory of Planned Behaviour was used in constructing the framework which measured service quality. The questionnaire survey method was used to obtain data related to the perception of life insurance policy holders towards their current insurance company. The analysis of 150 life insurance policy holders using multiple regression and SOBEL test showed that customer satisfaction plays a mediating role in the relationship between service quality and customer loyalty. In other words, the effect of mediation is present where service quality gives a positive impact on customer satisfaction, which subsequently gives a positive impact on customer loyalty. Further analysis also revealed that among the five dimensions in the SERVQUAL model, reliability played the most important role in determining customer satisfaction and customer loyalty. The outcome drawn from the current study offers insights for the insurance industry to focus on the dimensions that play a significant role in retaining and capturing more loyal customers. This will assist businesses in gaining profitability and sustainability.
\end{abstract}

Keywords: Customer Loyalty, Customer Satisfaction, Service Quality

ARTICLE INFO

Article History:

Received: 20 June 2021

Accepted: 01 November 2021

Available online: 01 December 2021

\footnotetext{
* Corresponding Author: Kamisah Ismail, Department of Accounting, Faculty of Business and Economics, University of Malaya, 50603 Kuala Lumpur, Malaysia; Email: kamisah.ismail@um.edu. my ; Tel: +603-79673804
} 


\section{INTRODUCTION}

Life insurance is an important substitute or replacement income for a family, in the event that a mishap happens to the breadwinner of that family. Hence, life insurance policies provide several benefits, such as savings for education, savings for retirement, tax benefits and protection against rising health expenses. In the Malaysian context, all insurance and takaful including life insurance is under the supervision of Bank Negara Malaysia (BNM) since 1988 (BNM, 2001). BNM issued standards and guidelines to govern and supervise all insurance and takaful operators in Malaysia. This industry has recorded a consistent growth for itself since then. The market growth of the life insurance industry is driven by the awareness of society on the importance of life insurance. As reported by the Life Insurance Association Malaysia (LIAM), the life insurance industry grew by $15.7 \%$, with the amount gained from new individual life business premiums amounting to RM 2.8 billion for the period from January to June 2014, as compared to RM 2.4 billion for the same period in year 2013. At present, there are 15 life insurance companies in Malaysia, yet the growth rate of this industry is still far behind that of the national mission of ensuring that $75 \%$ of the population is insured. According to LIAM, the penetration of life insurance is relatively low compared to other developed countries.

Life insurance companies are customer-oriented. Their main source of income is from policies purchased by customers. Existing customers' intention to repeat purchase is mainly affected by the loyalty of the customer towards the company (Goodman, 1999). Customer loyalty is one of the factors that leads the industry to profitability, and to accomplish its financial performance (Oliver, 1999). Even a small increase in customer loyalty (5 percent) could increase the profit by 25 to 85 percent (Reichheld \& Sasser, 1990). Thus, customer loyalty could bring a significant impact on the sustainability of a company.

In today's competitive market, what can a company provide to the customer to be able to stand out among its rivals? Since we know that the main sources of life insurance are from customers, therefore focus should be on customers. How to retain and attract customers? What can an insurance company do to encourage customers to repeat purchase and continue to renew their policies? Loyalty is the key word. Does the quality of service 
really affect customers' satisfaction that will then lead to customer loyalty? Is service quality really the main concern for customers in Malaysia to be loyal? Does customer satisfaction lead to customer loyalty?

This paper aims to examine the relationship between service quality, customer satisfaction, and customer loyalty, among life insurance customers in Malaysia. The study is important to the life insurance companies in Malaysia as it conducts a much needed survey on customers' perception of the relationship that they have with their insurance companies in terms of service, satisfaction, and loyalty. It is vital to conduct this study because the expectations of customers has been evolving due to the growing amount of information affected by advancing technology, and the availability of many competitive companies in the insurance industry. As the insurance companies are very much dependent on their clients (customers) to sustain, it is therefore very crucial to conduct a study focussing on insurance companies. Thus far, to the authors' knowledge, there is no published study on this area which used insurance companies, particularly life insurance, as their sample. Previous studies on service quality and customer loyalty have focussed on retail banking customers (Caruana, 2002; Kaura et al., 2015; Özkan, Süer, Keser \& Kocakoç, 2019, Yadav \& Rai, 2019), public electricity utility (Chodzaza \& Gombachika, 2013), individual shoppers at department stores (Gong \& Yi, 2018), hospitality industry (Myo, Khalifa \& Aye, 2019; Priyo, Mohamad \& Adetunji, 2019), supermarkets (Slack and Singh, 2020), and armed forces health organisations (Ismail et al., 2016). The outcome derived from this study is crucial as it could provide life insurance companies the information that could help them to enhance their current service quality for sustainable customer satisfaction and loyalty. Moreover, even though SERVQUAL is a well established measure for service quality, research done in Asian countries is very much lacking. Most of the studies in this area were conducted in Western countries. Different cultures might have different perceptions on service quality (Furrer, Liu \& Sudharshan, 2000), and the relationship among the variables. Western countries' perception on service quality, customer satisfaction and loyalty might differ from the perception of Asian countries such as Malaysia.

This paper will be organised in the following manner. The literature review and hypotheses development will be discussed in the next section, followed by research methodology, results and discussion. Finally, this paper 
concludes with some theoretical and practical implications, limitations, as well as suggestions for future research.

\section{LITERATURE REVIEW AND HYPOTHESES DEVELOPMENT}

\section{Service Quality}

Service quality can be associated with the impression of the customer (Bitner and Hubbert, 1994), judgement of overall performance (Parasuraman, 1998) and customer requirements (Anderson and Fornell, 1994). A customer's perceived quality is the determinant of what was expected and experienced during the delivery process. Service quality is measured between the expectation of service and perception about the service delivered (Parasuraman et al., 1988). Service quality may have an influence on the insurance industry because this industry is customer oriented. Prior studies have revealed that customers who are given good quality service and treated well tend to have a positive perception towards a company, and are more loyal and willing to pay a higher price for the products offered (Stamatis, 2018; Woods, 1999).

From a life insurance company perspective, it is important to provide good service experience and perception so that existing customers can be retained and to attract new ones. The success of a life insurance companies depends on the customers' choices and the quality of services provided (Siddiqui, Khand \& Sharma, 2010). Life insurance companies need to ensure what type of quality service is being offered to customers if it aims to win, attract and motivate more customers to engage with their companies. Good service quality not only retains existing customers; it also encourages them to purchase more products.

\section{Customer Satisfaction}

Customers' perception on the service quality provided will determine the level of their satisfaction. In the life insurance industry, customer satisfaction is an important element to the industry's success as it will generate a positive word-of-mouth message effect (Swan \& Oliver, 1989; 
Ali \& Raza, 2015). Customer satisfaction will also lead to customer loyalty (Anderson \& Fornell, 1994; Heskett, Jones, Loveman, Sasser \& Schlesinger, 1994; Chodzaza \& Gombachika, 2013; Kaura, Durga Prasad \& Sharma, 2015; Ismail, Omar Zaki \& Rose, 2016). The more satisfied the customers are, the better the retention of the customers by companies. This, can in turn, ensure higher profits for the company.

\section{Customer Loyalty}

In any service industry, customers are important, hence any ability to retain a customer is better than the challenge of seeking new customers (Gremler \& Brown, 1996). To do this, companies need to have strategies to retain their customers, such as building customer loyalty. Customer loyalty can be viewed in terms of behaviour and attitude. Purchase frequency, repeat purchase, recommendations, and willingness to pay a premium price are some of the customer loyalty behaviours (Anderson and Sullivan, 1993; Zeithaml et al. 1996). Customer loyalty has an important impact on the sustainability of a company as it could bring more profitability (Duncan \& Elliott, 2004). Many studies have been conducted on the variables that affect or are related to customer loyalty such as customer satisfaction and customer retention (Bahri-Ammari \& Bilgihan, 2019), service quality (Zeithaml et al., 1996), profitability (Reichheld et al., 2000) and many others.

\section{Theory of Planned Behaviour}

The Theory of Planned Behaviour was used to support the research model in Figure 1. This Theory was designed to predict and explain human behaviour in specific contexts (Ajzen, 1985; Ajzen, 1991). A central factor in the Theory is the individual's intention to perform a given behaviour. Intentions are assumed to capture the motivational factors that influence a behaviour. In this study, service quality (motivational factor) was expected to influence customer satisfaction, which will subsequently lead to customer loyalty (behaviour). 


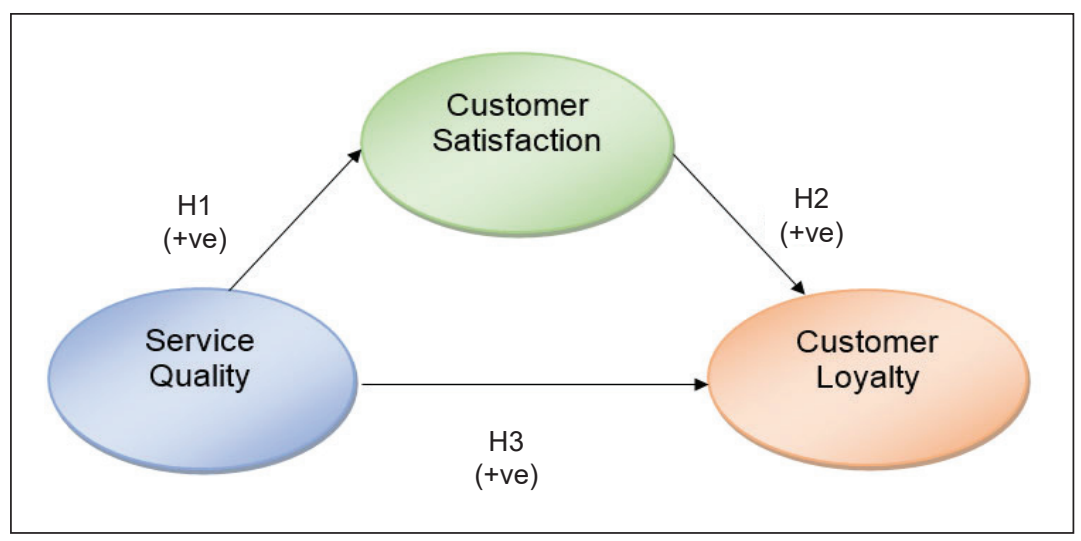

Figure 1: Research Model

\section{The Relationship Between Service Quality and Customer Satisfaction.}

Service quality is conceptualised differently from customer satisfaction even though both may be closely related (Parasuraman, Zeithaml \& Berry, 1994). While satisfaction is a broader concept, it may be influenced by many dimensions such as price, personal factors, product quality and many more. In contrast, service is often measured by its quality, hence service quality is more specific. It is linked to the various service dimensions (Zeithaml, Bitner \& Gremler, 2006). In this regard, service quality can be defined as a customer perception that is influenced by the five dimensions stated in the SERVQUAL model.

Research looking at these two variables in different industries have noted that there was a positive significant relationship between service quality and customer satisfaction. This includes the banking industry (Kumar, Kee \& Manshor, 2009; Ali \& Raza, 2015; Narteh, 2018; Yadav \& Rai, 2019), retail sector (Vesel \& Zabkar, 2009), telecommunications (Lai, Griffin \& Babin, 2009), and others. Customer satisfaction is measured in line with customer experience on a service encounter. When quality service is served, customers will be satisfied (Kaura et al., 2015; Ismail et al., 2016; Gong \& Yi, 2018: Slack and Singh, 2020). This means that an increase in service quality tends to lead to an increase in customer satisfaction. Therefore, the following hypothesis was formulated: 
H1: There is a positive relationship between service quality and customer satisfaction.

\section{The Relationship Between Customer Satisfaction and Customer Loyalty}

Customer satisfaction is said to be the major factor leading to customer loyalty (Wong, Tong \& Wong, 2014; Akroush \& Abu-ElSamen, 2012; Oliver, 1997; Anderson \& Sullivan, 1993; Cronin \& Taylor, 1992). It is believed that if a customer was satisfied with the services offered, or the services offered were above their expectations, positive words-of-mouth would disseminate among customers, thereby leading to future repeat purchases (Kaura et al., 2015; Ali \& Raza, 2015; Oliver, 1997). A satisfied customer has the tendency to remain with a company, whereas a dissatisfied customer would definitely be driven away. Anderson and Fornell (1994) pointed out that satisfaction is viewed as the antecedent of a relative attitude because satisfaction would lead consumers towards the loyalty of a brand, hence promoting brand loyalty. Based on this, the hypothesis formulated was:

H2: There is a positive relationship between customer satisfaction and customer loyalty

\section{The Relationship Between Service Quality and Customer Loyalty}

Service quality integrates the service provider and the customer. The success of an organisation is highly dependent on its relationship with its customers (Panda, 2003). There are limited number of studies focusing on the relationship between service quality and customer loyalty (Cronin, Brady \& Hult, 2000; Zeithaml, 2000). Loyalty can be viewed to be more significant in the service industry as compared to the tangible goods industry (Zeithaml, 1981). This is because service provides more interaction between people. Therefore, a quality service provider has a higher opportunity to gain more loyal customers (Parasuraman, Zeithaml \& Berry, 1985). Service quality can influence the outcome of an organisation, such as promoting customer loyalty (Newman, 2001; Chodzaza \& Gombachika, 2013; Ismail et al., 2016; Gong \& Yi, 2018; Budianto, 2019). Loyalty is also described as repurchasing, and the willingness to recommend; it has been found to 
have a positive relationship with service quality (Dean, 2002). Customers who experience poor service quality tend to feel unfavourable behavioural intentions (Oliver, 1997). Based on this, the following hypothesis was formulated:

H3: There is a positive relationship between service quality and customer loyalty

\section{The Mediating Role of Customer Satisfaction}

Service quality has a direct impact on customer satisfaction (AbuElSamen, Akroush, Al-Khawaldeh \& Al-Shibly, 2011). Good service quality would offer customers a positive experience. This positive customer experience affects the customer's purchase intention which is one of the determinants of customer loyalty. Therefore, service quality is necessary, but it is not sufficient to create customer loyalty unless service quality leads to customer satisfaction.

According to Baron and Kenny (1986), the mediator effect takes place when:

1. The independent variable (service quality) affects the mediator (customer satisfaction).

2. The independent variable (service quality) affects the dependent variable (customer loyalty).

3. The mediator (customer satisfaction) affects the dependent variable (customer loyalty) in the presence of the independent variable (service quality)

Hence, it can be hypothesised that:

H4: Customer satisfaction mediates the relationship between service quality and customer loyalty. 


\section{METHODOLOGY}

\section{Data Collection}

This study used a questionnaire survey as a data collection method. The questionnaire was divided into four parts. Part A focussed on the demographics of the respondents. Part B measured the independent variable (service quality). Part $\mathrm{C}$ measured the mediator (customer satisfaction) and Part D measured the dependent variable (customer loyalty). All questions relating to service quality, customer satisfaction, and customer loyalty were based on the 5-point Likert scale varying from 1 (Strongly Disagree) to 5 (Strongly Agree). The questionnaire was sent to the ten potential respondents (policy owner) for pilot testing, and to ten academicians for pre-testing. Several amendments were then made to the contents and the wordings of the questions, mainly to fine tune clarity, and face and content validity before the final version was sent to the respondents.

\section{Measurement of Variables}

The measurements for each variable had already been used and validated in many research. Service quality (independent variable) was adopted from the SERVQUAL model as suggested by Parasuraman, Zeithaml and Berry (1988). It measures consumers' perception on service quality by using 22 items. It consists of five dimensions: tangibles (physical facilities, equipment, and appearance of personnel), reliability (ability to perform the promised service dependably and accurately), responsiveness (willingness to help customers and provide prompt service), assurance (knowledge, ability and courtesy of employees to inspire trust and confidence), and empathy (caring, individualised attention the organisation provides its customers). The SERVQUAL model can be considered an established measurement for service quality as it has been used in many studies (E.g: Ismail et al., 2016; Narteh, 2018), among others. Customer satisfaction, which acted as a mediator, was adopted from Amin, Isa and Fontaine (2013). Customer loyalty (dependent variable) was adopted from Zeithaml et al. (1996), Vesel and Zabkar (2010), and Amin et al. (2013) with a slight modification to ensure comprehensiveness and suitability to the context of the study. Loyalty on intangible service was defined as related to the purchase, attitude, and cognition. Both customer satisfaction and customer loyalty measures consisted of 6 items, respectively. 


\section{Sampling Design}

The sampling population for this study consisted of individuals residing in Malaysia, and owning a life insurance policy. This study used simple random sampling. The target sample were adults aged 18 and above, and who owned a life insurance policy. This is because the legal life insurance policy owner must be of 18 years and above. The respondents were randomly invited to answer the questionnaire as long as they owned a life insurance policy. All respondents were from Peninsular Malaysia. The sample size used in this study was based on Tabachnick and Fidell's (2007) sample size calculation: $\mathrm{N}>50+8 \mathrm{~m}(\mathrm{~m}=$ number of independent variables) which equals to 58 respondents. However, to fulfil the factor analysis assessment, a minimum of 150 respondents are necessary to be considered as sufficient for the study (Tabachnick and Fidell, 2007).

\section{RESULTS AND DISCUSSION}

\section{Descriptive Analysis}

A total of 150 questionnaires were distributed almost equally to both male and female respondents, with the difference of 14 respondents. The total comprised $54.7 \%$ females and $45.3 \%$ males. The majority of the respondents (48.7\%) were aged between 30-39 years old, followed by other age groups. Ethnicity was divided into four categories and the Chinese comprised $48.7 \%$, the Malays comprised $38.7 \%$, the Indians comprised $10 \%$, and others made up $2.7 \%$. A total of 146 respondents out of 150 respondents possessed qualifications above the SPM (Sijil Peperiksaan Malaysia-O level). The respondents were mostly married (63.3\%) and this led to the majority household size comprising 2 to 5 people. The household income of the majority or $62 \%$ was above RM 6,000 . This indicated that the respondents had a stable income.

The average total number of insurance policies owned by the respondents were between two to three policies. Medical and health policies were the policies most purchased, as shown by the $83.3 \%$ of respondents who claimed to make such purchases. In this analysis, it appeared that investment-linked policies overtook the traditional whole life policies, in 
terms of ownership, with a difference of $3.3 \%$. The demographic profile of the respondents is summarized in Table 1.

Table 1: Demographic Profile of Respondents

\begin{tabular}{|c|c|c|c|}
\hline Variable & Category & Frequency & $\begin{array}{c}\text { Percentage } \\
(\%)\end{array}$ \\
\hline Gender & $\begin{array}{l}\text { Male } \\
\text { Female }\end{array}$ & $\begin{array}{l}68 \\
82\end{array}$ & $\begin{array}{l}45.3 \\
54.7\end{array}$ \\
\hline Age & $\begin{array}{l}18-29 \\
30-39 \\
40-49 \\
50 \& \text { above }\end{array}$ & $\begin{array}{l}23 \\
73 \\
40 \\
14\end{array}$ & $\begin{array}{c}15.3 \\
48.7 \\
26.7 \\
9.3\end{array}$ \\
\hline Race & $\begin{array}{l}\text { Malay } \\
\text { Chinese } \\
\text { Indian } \\
\text { Others }\end{array}$ & $\begin{array}{c}58 \\
73 \\
15 \\
4\end{array}$ & $\begin{array}{c}38.7 \\
48.7 \\
10.0 \\
2.7\end{array}$ \\
\hline Marital Status & $\begin{array}{l}\text { Single } \\
\text { Married } \\
\text { Divorced }\end{array}$ & $\begin{array}{c}51 \\
95 \\
4\end{array}$ & $\begin{array}{c}34.0 \\
63.3 \\
2.7\end{array}$ \\
\hline $\begin{array}{l}\text { Highest Level of } \\
\text { Education }\end{array}$ & $\begin{array}{l}\text { SPM \& below } \\
\text { STPM/Certificate/Diploma } \\
\text { Bachelor Degree/Master/PhD } \\
\text { Professional Qualification }\end{array}$ & $\begin{array}{c}4 \\
31 \\
107 \\
8\end{array}$ & $\begin{array}{c}2.7 \\
20.7 \\
71.3 \\
5.3\end{array}$ \\
\hline Household Size & $\begin{array}{l}1 \\
2-3 \\
4-5 \\
6 \text { \& above }\end{array}$ & $\begin{array}{c}15 \\
58 \\
72 \\
5\end{array}$ & $\begin{array}{c}10.0 \\
38.7 \\
48.0 \\
3.3\end{array}$ \\
\hline $\begin{array}{l}\text { Monthly Household } \\
\text { Income }\end{array}$ & $\begin{array}{l}\text { Less than RM } 2,000 \\
\text { RM } 2,001 \text { - RM } 4,000 \\
\text { RM } 4,001 \text { - RM } 6,000 \\
\text { RM } 6,000 \text { - RM } 8,000 \\
\text { Above RM } 8,000\end{array}$ & $\begin{array}{c}6 \\
12 \\
39 \\
37 \\
56\end{array}$ & $\begin{array}{c}4.0 \\
8.0 \\
26.0 \\
24.7 \\
37.3\end{array}$ \\
\hline Occupation & $\begin{array}{l}\text { Professionals } \\
\text { Management Level } \\
\text { Executives } \\
\text { Self-Employed } \\
\text { Housewife } \\
\text { Others }\end{array}$ & $\begin{array}{l}25 \\
55 \\
40 \\
16 \\
5 \\
9\end{array}$ & $\begin{array}{c}16.7 \\
36.7 \\
26.7 \\
10.7 \\
3.3 \\
6.0\end{array}$ \\
\hline $\begin{array}{l}\text { No of policies bought } \\
\text { from the same insurer }\end{array}$ & $\begin{array}{l}1 \\
2-3 \\
4-5 \\
6 \& \text { above }\end{array}$ & $\begin{array}{l}39 \\
73 \\
27 \\
11\end{array}$ & $\begin{array}{c}26.0 \\
48.7 \\
18.0 \\
7.3\end{array}$ \\
\hline Type of policies & $\begin{array}{l}\text { Whole life } \\
\text { Term } \\
\text { Endowment } \\
\text { Investment-Link } \\
\text { Medical \& Health }\end{array}$ & $\begin{array}{c}75 \\
22 \\
39 \\
80 \\
125\end{array}$ & $\begin{array}{l}50.0 \\
14.7 \\
26.0 \\
53.3 \\
83.3\end{array}$ \\
\hline
\end{tabular}




\section{Results of Hypotheses Testing}

\section{Service quality (SQ) and customer satisfaction (CS)}

Table 2 shows the results of the multiple regression analysis. The mediator - customer satisfaction, was considered as a dependent variable. As noted in the table, the R Square value of 0.848 indicated that service quality explained 84.8 percent of the variance in customer satisfaction. The result also showed that service quality had a positive relationship with customer satisfaction. The significance value was less than 0.05 , thereby indicating that service quality made a significant contribution to the prediction of customer satisfaction $(\beta=.921, \mathrm{p}<0.05)$. In this regard, hypothesis $\mathrm{H} 1$ was supported. This result is consistent with previous research (Parasuraman, 1998; Ali \& Raza, 2015; Gong \& Yi, 2018; Narteh, 2018) which explains that service quality has a positive impact on customer satisfaction. Based on this, it can be concluded that if a company provides quality service to customers, it could lead to satisfaction among customers.

Table 2: Results of Multiple Regression Analysis

\begin{tabular}{cccccc}
\hline Hypothesis & Relationship & $\mathbf{R}^{\mathbf{2}}$ & $\begin{array}{c}\text { Constant } \\
\text { (Alpha) }\end{array}$ & Beta & p-value \\
\hline $\begin{array}{c}\text { H1 } \\
\text { (Direct) }\end{array}$ & SQ and CS & 0.848 & 0.142 & 0.921 & 0.000 \\
H2 & CS and CL & 0.864 & 0.256 & 0.929 & 0.000 \\
$\begin{array}{c}\text { (Direct) } \\
\text { H3 }\end{array}$ & SQ and CL & 0.783 & 0.003 & 0.885 & 0.000 \\
$\begin{array}{c}\text { (Direct) } \\
\text { H4 }\end{array}$ & SQ and CL & 0.869 & 0.109 & 0.192 & 0.013 \\
(Indirect) & CS and CL & & & 0.753 & 0.000 \\
\hline
\end{tabular}

\section{Customer satisfaction (CS) and customer loyalty (CL)}

As depicted in Table 2, the R Square value of 0.864 indicated that customer satisfaction explained 86.4 per cent of the variance in customer loyalty. The result also showed that customer satisfaction had a positive relationship with customer loyalty, as noted in the beta value of 0.929 . Moreover, the significance value was less than 0.05 , thereby indicating that customer satisfaction made a significant contribution to the prediction of customer loyalty $(\beta=.929, \mathrm{p}<0.05)$. In this regard, hypothesis $\mathrm{H} 2$ was supported. This finding is consistent with previous studies (Eg.; Wong et al., 2014; Akroush \& Abu-ElSamen, 2012) which found that satisfaction is an 
important antecedent to customer loyalty. Satisfied customers tend to engage with the same service provider due to their loyalty (Kaura et al., 2015).

\section{Service quality (SQ) and customer loyalty (CL)}

The R Square value of 0.783 indicated that service quality explained 78.3 per cent of the variance in customer loyalty. The result showed that service quality had a positive relationship with customer loyalty, as can be noted in the beta value of 0.885 . Further, the significance value was less than 0.05 , thereby indicating that service quality made a significant contribution to the prediction of customer loyalty $(\beta=.885, p<0.05)$. In this regard, hypothesis $\mathrm{H} 3$ was supported. As expected, service quality is one of the determinants of customer loyalty (Caruana. 2002; Chodzaza \& Gombachika, 2013; Ismail et al., 2016; Gong \& Yi, 2018; Budianto, 2019).

\section{Service quality (SQ), customer satisfaction (CS) and customer loyalty (CL)}

Multiple regression analysis was used to further test the hypotheses. As depicted in Table 2, both service quality and customer satisfaction had a positive relationship towards customer loyalty. Customer satisfaction had a stronger contribution towards customer loyalty $(\beta=.753, p<0.05)$ as compared to service quality $(\beta=.192, p<0.05)$. The beta value of 0.753 in comparison to 0.192 revealed the difference in contribution from both variables. Clearly, both service quality and customer satisfaction carried a significance value of less than 0.05 . This showed that both variables had a significant relationship with customer loyalty.

The multiple regression results above can be put in an equation as:

$$
\mathrm{CL}=0.109+0.192 \mathrm{SQ}+0.753 \mathrm{CS}+\mathrm{e}
$$

Where;

$\mathrm{CL}=$ Customer Loyalty

$\mathrm{SQ}=$ Service Quality

$\mathrm{CS}=$ Customer Satisfaction

$\mathrm{e}=$ error term 


\section{Mediation Effect}

The results of the multiple regression further showed that the requirement needed to activate the mediation effect was present. The beta value of service quality on customer loyalty was much less in the fourth equation as compared to the third equation. Perfect mediation did not occur since the beta for the service quality in the fourth equation was still significant $(p<0.05)$. Nevertheless, a mediation effect can be confirmed as the beta value declines dramatically (Caruana, 2002).

\section{Sobel Test}

The Sobel test was carried out to support the findings of the mediating effect of customer satisfaction, on service quality and customer loyalty (Baron \& Kenny, 1986). The Sobel test performs best and converges closely with sample sizes greater than 50 or so (MacKinnon, Warsi \& Dwyer, 1995). The test is conducted by using a web-based online calculator (Preacher \& Leornardelli, 2010). The details of the coefficient and standardised error on the relationship between service quality and customer satisfaction are then followed by the relationship between customer satisfaction and customer loyalty. Both the coefficient and standardised error value are obtained from the regression analysis through the SPSS. Preacher and Hayes (2004) and Preacher and Leonardelli (2010) indicated that if the $p$-value $<0.05$, then there is evidence of mediation.

Table 3: Results of Sobel Test

\begin{tabular}{lcc}
\hline & Coefficients & Standard error \\
\hline Service Quality to Customer Satisfaction & 1.052 & 0.037 \\
Customer Satisfaction to Customer Loyalty & 0.746 & 0.076 \\
& Test Statistic & $\boldsymbol{p}$-value \\
Sobel Test & 9.27842 & 0.00 \\
\hline
\end{tabular}

As shown in Table 3 show the result for the test statistic for the Sobel test was 9.27842 with a $p$-value of 0.00 . The $p$-value was below the alpha level of 0.05 , thereby indicating the evidence of mediation (Preacher \& Hayes, 2004; Preacher \& Leornardelli, 2010). In this regard, hypothesis H4 was supported. This finding is consistent with the findings of Caruana 
(2002), Chodzaza and Gombachika (2013), Kaura et al. (2015), Ismail et al. (2016), and Slack and Singh (2020) among others, even though based in different contexts.

\section{Additional Analysis (Pearson Correlation)}

The Pearson Correlation analysis was then used to measure the strength and the direction of the relationship between the two variables. This additional analysis examined the five dimensions in the SERVQUAL model to detect which of them had the most significant impact on customer satisfaction and customer loyalty. The results as in Table 4 show that all the five dimensions were significantly related to customer satisfaction and customer loyalty. It appears that reliability has the most impact on customer satisfaction and customer loyalty. The strength of the correlation is followed by assurance, tangibles, and empathy for both customer satisfaction and customer loyalty. Responsiveness has the least impact on both customer satisfaction and customer loyalty. These findings are also noted to be quite consistent with past studies which observe that reliability is the core aspect of the service. It is mainly associated with the service outcome while other dimensions (tangibles, responsiveness, empathy and assurance) are associated with the deliverance of service (Parasuraman, Berry \& Zeithaml, 1991).

Table 4: Results of Pearson Correlation Analysis

\begin{tabular}{|c|c|c|c|c|c|}
\hline \multirow[b]{2}{*}{$\begin{array}{l}\text { Service Quality } \\
\text { dimension }\end{array}$} & \multicolumn{2}{|c|}{$\begin{array}{l}\text { Customer } \\
\text { Satisfaction }\end{array}$} & \multicolumn{2}{|c|}{$\begin{array}{l}\text { Customer } \\
\text { Loyalty }\end{array}$} & \multirow[b]{2}{*}{ Test result } \\
\hline & $\begin{array}{l}\frac{c}{0} \\
\frac{0}{\pi} \\
\frac{\pi}{0} \\
0 \\
0 \\
0\end{array}$ & $\begin{array}{l}\frac{0}{2} \\
\frac{1}{\pi} \\
\frac{1}{2}\end{array}$ & $\begin{array}{l}\frac{c}{0} \\
\frac{0}{\pi} \\
\frac{\pi}{0} \\
\frac{0}{0} \\
0\end{array}$ & $\begin{array}{l}\frac{0}{2} \\
\frac{1}{\pi} \\
\frac{1}{2}\end{array}$ & \\
\hline Tangibles & 0.840 & 0.000 & 0.820 & 0.000 & Supported \\
\hline Reliability & 0.894 & 0.000 & 0.867 & 0.000 & Supported \\
\hline Responsiveness & 0.694 & 0.000 & 0.660 & 0.000 & Supported \\
\hline Assurance & 0.872 & 0.000 & 0.846 & 0.000 & Supported \\
\hline Empathy & 0.768 & 0.000 & 0.723 & 0.000 & Supported \\
\hline
\end{tabular}




\section{CONCLUSION}

This study has provided evidence highlighting the importance of service quality and customer satisfaction on customer loyalty in the life insurance business in Malaysia. The outcome of this study supports the service quality model that was introduced by Parasuraman et al. (1988). All the four hypotheses which focused on the relationships among these three variables were found to be significant. Following Preacher and Hayes (2004), and Preacher and Leornardelli (2010), the SOBEL test was also done. It was observed that the effect of mediation was present where customer service quality impacted on customer satisfaction, and customer satisfaction impacted on customer loyalty, in the context of the life insurance business in Malaysia.

This study, therefore, has narrowed the gap between customer expectations and their perception of the service quality of the life insurance industry in Malaysia. As the life insurance customers' expectations converged with their perception of the service quality, they were more inclined to become satisfied, hence their loyalty could be obtained. Customer loyalty helps to ensure more benefits for the life insurance companies, for example, advertising for the companies by positive word of mouth, and/or repeat purchases, both of which would greatly contribute to the sustainability and profitability of the companies concerned. This study also revealed that reliability and assurance in the service quality dimension play an important role in customer satisfaction and customer loyalty.

This study has both theoretical and practical implications. From the theoretical perspective, as this study used the Theory of Planned Behaviour to support and explain the theoretical concept, as mentioned earlier, the central factor in this Theory is the individual's intention to perform a given behaviour. Intentions are assumed to capture the motivational factors that influence a behaviour. In this study, service quality (motivational factor) was found to influence customer satisfaction, which subsequently led to customer loyalty (behaviour).

In addition, the findings confirm that customer satisfaction mediates the relationship between service quality and customer loyalty. This paper signifies the importance of service quality in the life insurance business, 
and their impact on customer satisfaction and loyalty, with the use of the SOBEL test for the mediation effect. Thus far, to the authors' knowledge, there is no published study in this area that used the SOBEL test for this kind of relationship. Furthermore, this study also examined the five dimensions in the SERVQUAL model that had the most significant impact on customer satisfaction and customer loyalty.

As for practical implications, the paper has great significance for the life insurance business. The findings could serve as a guideline for the strategic planning of insurance companies in Malaysia. It is hoped that continuous research on consumer behaviour is conducted on the heterogeneity of customers. This is because the insurance company is required to put in more efforts with more innovations so as to satisfy customers. A customer service quality improvement strategy would definitely bring some differentiation to the life insurance industry which desires to stand out among its competitors.

This study is also restricted by some limitations. As such, there are ample opportunities to extend this study further. First, this study focused on customer satisfaction as a mediating variable. Future research should consider not only mediators but also potential suppressors such as moderators and contingent factors that might conceal or influence the relationship linking the independent variable (service quality) to the dependent variable (customer loyalty). Factors such as behavioural or ethical values are also worth researching. Second, the scales employed in this study were based on individuals' perceptions. Therefore, they may not reflect objective reality. Future studies could replicate the current study by utilising different methodologies such as experiments and case studies.

\section{REFERENCES}

Abu-ELSamen, A. A., Akroush, M. N., Al-Khawaldeh, F. M., \& Al-Shibly, M. S. (2011). Towards an Integrated Model of Customer Service Skills and Customer Loyalty. International Journal of Commerce and Management, 21(4), 349 - 380. doi: 10.1108/10569211111189365.

Ajzen, I. (1985). From intentions to actions: A theory of planned behavior. In J. Kuhi \& J. Beckmann (Eds.), Action-control: From cognition to behavior (pp. 11ó39). Heidelberg: Springer. 
Ajzen, I. (1991). The Theory of Planned Behavior. Organizational Behavior and Human Decision Processes, 50, 179-211.

Akroush, M. N., \& Abu-ElSamen, A. A. (2012). An empirical investigation of the mediating role of relationship marketing skills on the relationship between customer satisfaction and customer loyalty. International Journal of Internet Marketing and Advertising, 7(1), 1-30.

raza, M., \& Raza, S. A. (2015). Service quality perception and customer satisfaction in Islamic banks of Pakistan: the modified SERVQUAL model. Total Quality Management \& Business Excellence, 28(5-6), 1-19. doi: 10.1080/14783363.2015.1100517.

Amin, M., Isa, Z., \& Fontaine, R. (2013). Islamic Banks: Contrasting the drivers of customer satisfaction on image, trust, and loyalty of Muslim and non-Muslim customers in Malaysia. International Journal of Bank Marketing, 31(2), 79 - 97. doi: 10.1108/02652321311298627.

Anderson, E. W., \& Sullivan, M. W. (1993). The Antecedents and Consequences of Customer Satisfaction for Firms. Marketing Science, 12(2), 125-43. doi: 10.1287/mksc.12.2.125.

Anderson, E. W., \& Fornell, C. (1994). A Customer Satisfaction Research Prospectus. In R. T. Rust, \& R. L. Oliver (Eds.), Service quality: New directions in Theory and Practice (pp. 241-269).

Bahri-Ammari, N., \& Bilgihan, A. (2019). Customer retention to mobile telecommunication service providers: the roles of perceived justice and customer loyalty program. International Journal of Mobile Communications, 17(1). doi.org/10.1504/IJMC.2019.096518.

Bank Negara Malaysia (2001). Insurance Sector. In Financial Sector Masterplan 2001-2010, 62-74.

Baron, R. M., \& Kenny, D. A. (1986). The Moderator-Mediator Variable Distinction in Social Psychological Research: Conceptual, Strategic and Statistical Considerations. Journal of Personality and Social Psychology, 51(6), 1173-82. 
Bitner, M.J. and Hubbert, A.R. (1994). Encounter Satisfaction Versus Overall Satisfaction Versus Service Quality: the consumer's voice. In Rust, R. T. and Oliver, R. L. (Eds), Service Quality: New Directions in Theory and Practice. Thousand Oaks, CA: SAGE Publications, Inc.

Budianto, A. (2019). Customer Loyalty: Quality of Service. Journal of Management Review, 3(1), 299-305. doi: 10.25157/jmr.v3i1.1808.

Caruana, A. (2002). Service loyalty: The effects of service quality and the mediating role of customer satisfaction. European Journal of Marketing, 36(7/8), 811 - 828. doi: 10.1108/03090560210430818.

Chodzaza, G. E., \& Gombachika, H. S. H. (2013). Service quality, customer satisfaction and loyalty among industrial customers of a public electricity utility in Malawi. International Journal of Energy Sector Management, 7(2), 269-282. doi:10.1108/IJESM-02-2013-0003.

Cronin, J. J. \& Taylor, S. A. (1992). Measuring Service Quality: A ReExamination and Extension. Journal of Marketing, 56(3), 55-68. doi: $10.1177 / 002224299205600304$.

Cronin, J. J., Brady, M. K., \& Hult, G. T. M. (2000). Assessing the effects of quality, value, and customer satisfaction on consumer behavioral intentions in service environments. Journal of Retailing, 76(2), 193218. doi: 10.1016/S0022-4359(00)00028-2.

Dean, A. M. (2002). Service Quality in Call Centres: Implications for Customer Loyalty. Managing Service Quality: An International Journal, 12(6), 414 - 423. doi: 10.1108/09604520210451894.

Duncan, E. and Elliott, G. (2004). Efficiency, customer service and financial performance among Australian financial institutions. International Journal of Bank Marketing, 22(5), 319-342. doi: 10.1108/02652320410549647.

Furrer, O., Liu, B. S.-C., \& Sudharshan, D. (2000). The relationships between culture and service quality perceptions: Basis for cross-cultural market segmentation and resource allocation. Journal of Service Research, 2(4), 355-371. 
Gong, T., \& Yi, Y. (2018). The effect of service quality on customer satisfaction, loyalty, and happiness in five Asian countries. Psychology \& Marketing, 35(6), 427-442. doi: https://doi.org/10.1002/mar.21096.

Goodman, J. (1999). Quantifying the impact of great customer service on profitability. In R. Zemke \& J. A. Woods (Eds), Best Practices in Customer Service (pp. 17-29). American Management Association, HRD Press, Amherst, MA, (first AMACOM edition).

Gremler D. D, \& Brown S. W. (1996). Service Loyalty: Its Nature, Importance and Implications. New York: International Service Quality Association. pp. 171-180.

Heskett, J. L., Jones, T. O., Loveman, G. W., Sasser, W. E., \& Schlesinger, L. A. (1994). Putting The Service Profit Chain To Work. Harvard Business Review, March-April, 164-174.

Ismail, A., Omar Zaki, H., \& Rose, I. R. (2016). Interlinkages between service quality, customer satisfaction and customer loyalty in Malaysia: A case study of Armed Forces Medical Organizations. Malaysian Journal of Society and Space, 12(7), 47 - 59.

Kaura, V., Durga Prasad, C. S., \& Sharma, S. (2015). Service Quality, Service Convenience, Price and Fairness, Customer Loyalty, and the Mediating Role of Customer Satisfaction. International Journal of Bank Marketing, 33(4), 404-422. doi: 10.1108/IJBM-04-2014-0048.

Kumar, M., Kee, F. T., Manshor, A. T. (2009). Determining the Relative Importance of Critical Factors in Delivering Service Quality of Banks: An application of dominance analysis in SERVQUAL model. Managing Service Quality: An International Journal, 19(2), 211-228. doi: 10.1108/09604520910943198.

Lai, F., Griffin, M., \& Babin, B. J. (2009). How Quality, Value, Image and Satisfaction Create Loyalty at a Chinese Telecom. Journal of Business Research, 62(10), 980 - 986. doi: 10.1016/j.jbusres.2008.10.015. 
Life Insurance Association Malaysia (LIAM). (2013). 2012 Underinsurance Study in Malaysia. Retrieved October, 2015, from http://www.liam.org. my/pdf/gapreport-draft.pdf

MacKinnon, D. P., Warsi, G., \& Dwyer, J. H. (1995). A simulation study of mediated effect measures. Multivariate Behavioural Research, 30(1), 41 .

Myo, Y. N., Khalifa, G. S., \& Aye, T. T. (2019). The Impact of Service Quality on Customer Loyalty of Myanmar Hospitality Industry: The Mediating Role of Customer Satisfaction. International Journal of Management and Human Science, 3(3), 1-11.

Narteh, B. (2018). Service quality and customer satisfaction in Ghanaian retail banks: the moderating role of price. International Journal of Bank Marketing, 36(1), 68-88. doi: 10.1108/IJBM-08-2016-0118.

Newman, K. (2001). Interrogating SERVQUAL: A Critical Assessment of Service Quality Measurement in a High Street Retail Bank. International Journal of Bank Marketing, 19(3), 126-139. doi: 10.1108/02652320110388559.

Oliver, R. L. (1997). Satisfaction: A Behavioral Perspective on the Consumer. New York: McGraw-Hill.

Oliver, R. L. (1999). Whence Consumer Loyalty? Journal of Marketing, $63,33-44$.

Özkan, P., Süer, S., Keser, İ. K., \& Kocakoç, İ. D. (2019). The effect of service quality and customer satisfaction on customer loyalty: The mediation of perceived value of services, corporate image, and corporate reputation. International Journal of Bank Marketing, 38(2), 384-405. doi: 10.1108/IJBM-03-2019-0096.

Panda, T. K. (2003). Creating Customer Lifetime Value through Effective CRM in Financial Services Industry. Journal of Services Research, 2(2), 157-171. 
Parasuraman, A., Zeithaml, V.A., \& Berry, L. L. (1985). A Conceptual Model of Service Quality and Its Implications for Future Research. Journal of Marketing, 49(4), 41-50. doi: 10.1177/002224298504900403.

Parasuraman, A., Zeithaml, V.A., \& Berry, L.L. (1988). SERVQUAL: A Multiple-Item Scale for Measuring Consumer Perceptions of Service Quality. Journal of Retailing, 64(1), 12-37.

Parasuraman, A., Berry, L. L., \& Zeithaml, V. A. (1991). Refinement and reassessment of the SERVQUAL scale. Journal of Retailing, 67(4), 420.

Parasuraman, A., Zeithaml, V. A., \& Berry, L. L. (1994). Alternative Scales for Measuring Service Quality: A Comparative Assessment Based on Psychometric and Diagnostic Criteria. Journal of Retailing, 70(3), pp. 201-30.

Parasuraman, A. (1998). Customer Service in Business-to-Business Markets: An Agenda for Research. Journal of Business \& Industrial Marketing, 13(4/5), 309-321. doi: 10.1108/08858629810226636.

Preacher, K. J., \& Hayes, A. F. (2004). SPSS and SAS procedures for estimating indirect effects in simple Mediation models. Behavior Research Methods, Instruments, \& Computers, 36(4), 717-731.

Preacher, K. J., \& Leonardelli, G. J. (2010). Calculation for the Sobel test: An Interactive Calculation Tool for Mediation Tests. Retrieved from http://quantpsy.org/sobel/sobel.htm

Priyo, J. S., Mohamad, B., \& Adetunji, R. R. (2019). An examination of the effects of service quality and customer satisfaction on customer loyalty in the hotel industry. International Journal of Supply Chain Management, 8(1), 653-663.

Reichheld, F. \& Sasser, W. E. Jr. (1990). Zero defections: quality comes to services. Harvard Business Review, 5, 105-111.

Reichheld, F., Markey, R., \& Hopton, C. (2000). The Loyalty Effect - The Relationship between Loyalty and Profits. European Business Journal, $20,134-139$. 
Siddiqui, M. H., Khand, V., \& Sharma, T.G. (2010). Measuring the customer perceived service quality for life insurance services: an empirical investigation. International Business Research, 3(3), 171-186.

Slack, N. J., \& Singh, G. (2020). The effect of service quality on customer satisfaction and loyalty and the mediating role of customer satisfaction: Supermarkets in Fiji. The TQM Journal, 32(3), 543-558. doi: 10.1108/ TQM-07-2019-0187.

Stamatis, D. H. (2018). Total quality service: principles, practices, and implementation. Routledge.

Swan, J. E., \& Oliver, R. L. (1989). Postpurchase Communications by Consumers. Journal of Retailing, 65(4), 516-33.

Tabachnick, B. G., \& Fidell, L. S. (2007). Using multivariate statistics. Boston: Pearson Education.

Vesel, P., \& Zabkar, V. (2009). Managing customer loyalty through the mediating role of satisfaction in the DIY retail loyalty program. Journal of Retailing and Consumer Services, 16(5), 396-406. doi: 10.1016/j. jretconser.2009.05.002.

Vesel, P., \& Zabkar, V. (2010). Relationship quality evaluation in retailers' relationships with consumers. European Journal of Marketing, 44(9/10), 1334 - 1365. doi: 10.1108/03090561011062871.

Wong, R., Tong, C., \& Wong, A. (2014). Examine the Effects of Customer Satisfaction on Customer Loyalty: An Empirical Study in the Healthcare Insurance Industry in Hong Kong. British Journal of Economics, Management \& Trade, 4(3), 372-399.

Woods, J. A. (1999). Customer service, value, and the systems view. In R. Zemke \& J. A. Woods (Eds), Best Practices in Customer Service (pp. 3-9). American Management Association, HRD Press, Amherst, MA, (first AMACOM edition). 
Yadav, M. K., \& Rai, A. K. (2019). An Assessment of the Mediating Effect of Customer Satisfaction on the Relationship Between Service Quality and Customer Loyalty. IUP Journal of Marketing Management, 18(3), 7-23.

Zeithaml, V. A. (1981). How Consumer Evaluation Processes Differ for Products and Services. In J. Donnelly \& W. George (Eds), Marketing of Services (pp. 186-190). Chicago: American Marketing.

Zeithaml, V. A. (2000). Service Quality, Profitability, and the Economic Worth of Customers: What We Know and What We Need to Learn. Journal of the Academy of Marketing Science, 28(1), 67-85. doi:10.1177/0092070300281007.

Zeithaml, V. A., Berry, L. L., \& Parasuraman, A. (1996). The behavioral consequences of service quality. Journal of marketing, 60(2), 31-46.

Zeithaml, V.A., Bitner, M.J., \& Gremler, D.D. (2006). Services marketing: integrating customer focus across the firm. Singapore: McGraw-Hill. 